\title{
ANALYZING THE HISTORICAL PERSPECTIVE OF TALIBAN IN ORDER TO UNDERSTAND THE RE-EMERGENCE OF TALIBAN AND FUTURE PROSPECTS FOR NEIGHBORING COUNTRIES
}

\author{
Shaukat \\ Lecturer, Department of Political Science, \\ Abdul Wali Khan University Mardan \\ shaukat@awkum.edu.pk \\ Suhrab Ahmad \\ Lecturer, Department of Political Science, \\ University of Chitral, Chitral \\ suhrab@uoch.edu.pk \\ Nelofar Ihsan \\ Lecturer \\ Department of Political Science, \\ Abdul Wali Khan University Mardan \\ nelofar.Ihsan@yahoo.com
}

\begin{abstract}
Afghanistan has been a focal state when it comes to international politics. With the advent of Taliban in Afghanistan, it has become central point of attention. The whole world is oblivious to Taliban's strategic moves. Therefore, it is imperative to comprehend that Afghanistan's socio-politico circumstances since the very start were dampened by the connectivity issue, which aggravated the political landscape of Afghanistan in order to understand the current scenario. This paper is an attempt to comprehend the current situation through a historical lens of understanding the emergence of Taliban in the first place. This paper shall also identify the historical emergence through chronological order and then shall see Taliban emergence and changing dynamics of neighboring countries.
\end{abstract}

Keywords: Taliban, Perspective, Afghanistan, Strategic view, Neighboring Countries

\section{INTRODUCTION}

Afghanistan has been a focal point for different political transformations spanning over thirty years. Starting from socio-cultural-politic, each fragment has collapsed so that there is no central point that holds all the other segments together (Schirch, Rafiee, Sakhi \& Vardak, 2011). However, since the polity of Afghanistan has had no central power to hold things altogether, this provided a breeding ground for extremist factors to emerge. The lack of central command in Afghanistan led to partisan and ethical uprisings. These uprisings were limited within national boundaries, but they had aftermaths on their neighboring states of Central Asia, Russia, China, Iran and Pakistan. The deteriorating state of affairs led to governance failures providing loopholes for extremism, and so the non-state actors to become significant. Their significance led to turmoil in state affairs, contributing to the rise in extremist ideology. Due to the absence of strong political leadership, these extremist actors could get their hands on military equipment. The militarization of these extremist actors led to an environment of instability for its inhabitants and its neighboring borders. Historically, colonial based structures were developed in mid19th century. The geographical diversification of Afghanistan prevented it from being operated through a centralized program (Gagnon, 2012). A combination of geographical hurdles and impotent governance policies by the British impeded the region to arrange its state of affairs. Afghanistan had been home to Tribal belts, and the imposition of westernization was considered a threat to their cultural norms, values, and ideological beliefs. This division led to the stratification of Pashtun tribes, who then ascended 
themselves towards borderline migrating from the center. Although the organizational collapse of the Afghan Monarchy took place in mid-20th century, the colonial empire regenerated an ally monarchy that was formulated just for the West ridge interests of colonial powers. The result of this interest-based Monarchy was that it served its masters well and gradually inculcated western norms of governance, i.e., government structures and the manifestation of armed forces for the protection of its subjects (Lubna Sunawar, 2021). This paper is an attempt to comprehend the current situation through a historical lens of understanding the emergence of Taliban in the first place. While an ample literature on Taliban and their emergence is present, linking that literature to the new dynamics is something that is still understudied. Therefore, this paper shall (i) identify the historical emergence through chronological order and then shall see (ii) Taliban emergence and changing dynamics of the neighboring countries.

\section{Historical perspective of the emergence of Taliban}

The Afghan government received considerable amounts of economic and military support from the USSR and economic assistance from the United States during the cold war era. These resources empowered the state to take up the least updated education, communication, and industrialization projects that need a closer connection between the capital and the outskirts. These supplementing abilities protected the endeavor of the state (Riaz, 2020). The downfall of the kingship of Afghan in 1978, followed the Soviet invasion in 1979, and the presence of substantial Soviet military during the era of 1980s resulted in the militarization of the afghan borderline by the United States, facilitated by Saudi Arabia and Pakistan. The historical ethno linguistic, sectarian and regional divisions in Afghanistan were worsened by introducing enormous weapons and funds. It also encouraged alternative social and political structures and processes of local governance in the periphery. The rising and boldly expressed ethnic and sectarian divisions were to be repeated within the organization and in the operation of several American-sponsored mujahidin groups (labelled as "Freedom Fighters"). These groups energetically competed for the natural and the political favors of their Western benefactors. Occasional conflicts arose in the field among the mujahidin because of these fault trends produced. These conflicts were produced especially between the period of withdrawal of Soviet forces in 1989 and the complete withdrawal of the United States from the region in 1992 (Marks, 2012). After the withdrawal of the United States from the region, the Taliban movement emerged and also during the riot that broke out the downfall of the Afghan central government in 1992.

After 1978, political and social instability allowed millions of Afghan men to engage in numerous types of antagonism to the state and the unrestricted and illegal movements of commodities like drugs across the international borders (Krambs, 2012). They experienced immediate vulnerability, the absence of the Afghan state and the possibility of local rules as a drooping and ultimate diminishing of central powers. Euro-American neo-colonialism in Afghanistan is controlled by policies and strategies predicated on economics, globalization, and cultural imperialism widely distributed in Western media on Afghanistan by different analysts, strategists, experts, and academic specialists. They argue that if the United States had continued its support of mujahidin after 1989 and especially after 1992, the collapse of the state composition of Afghanistan could have been prevented (Marks, 2012). However, this argument is denied by the political and cultural realities on the ground. The downfall of the state structure of Afghanistan and the enthusiasm of Islam began long before the Soviet Union left the country in 1989 (Gagnon, 2012). When the United States assumed sponsorship of the mujahidin in early 1980, right after that started the radicalization of Islam in Afghanistan. The termination of the US subsidies for the mujahidin and the withdrawal of the Soviets, by that very fact, have little to do with the emergence of the Taliban, the collapse of the state of Afghanistan and the puncturing of the Country by Al-Qaida.

A lot of factors have led to the collapse of Afghan governance structure; starting from the deteriorating conditions of state affairs which resulted in governance failures to allowing extremist nonstate groups to gain a significant strength. The importance of Taliban caused a turmoil in state affairs, which aided the emergence of extremist ideology. Taliban were able to get military equipment due to the lack of a strong political leadership in Afghanistan. The militarization of Taliban created a climate of insecurity not just for the people living there, but also for those living near the country's borders (Ehlke, 2010). In 2020, United States signed the second peace treaty with Taliban ensuring the withdrawal of 
troops within fourteen months. The negotiations went underway in Doha but after the US evacuation from Afghanistan in August 2021, Taliban achieved what was nothing less than a magical story. They were able to take control of Afghanistan in a matter of nine days. On the eve of 14thAugust 2021, Taliban surrounded Kabul and without any bloodshed the Afghan government surrender making it possible for the Taliban to enter the city and take charge on $15^{\text {th }}$ of August. However, this change of command has led to a lot of speculations. More than people appreciating the Taliban this change of command are people who fear sustainability and its implication in global politics.

\section{Re- emergence of Taliban, implications for Iran, China and Russia}

Afghanistan has collapsed after the Soviet Union's dissolution in 1994. Afghanistan was divided into a patchwork of opposing groups or teams. President Rabbani's mostly inherited Tajik governmentcontrolled Kabul and the northeast of the country, while Abdul Rashid Dostum ruled the Northern provinces and warlords. Ismail Khan was in charge of the western provinces surrounding Herat (Marks, 2012). Gulbuddin Hekmatyar and other warlords seized control of the area to the south and east of Kabul. The eastern border with Pakistan was controlled by a mujahedin council, while the south was split between ex-mujahidin and bandits who utilized their control of the routes to gain revenue from crossborder trade with Pakistan.

The origins of the Taliban's are a source of conjecture. As per trustworthy reports, two females from a neighboring Afghan tribe were abducted and assaulted by a team of Mujahedeen, and the Taliban supported the family in returning the imprisoned girls after destroying mujahedin bases. According to the informant, the Taliban also saved a boy who had been tried for rape by many Mujahedeen units (Ehlke, 2010). The Taliban's shining reputation started to permeate in Afghanistan, and locals started to observe Mullah Umar as a savior. Though much of the West has been astonished by the Taliban's swift march into Kabul, Afghans will bear the weight of the militant team's power. The instant effect will be noticed by Afghanistan's neighbors outside its boundaries. Previously this year, Russia, China, and Pakistan agreed that the future of Afghanistan must be decided by communication and democratic agreements. With Taliban in power now, a lot of speculations have been risen, starting off with the possible options available for neighbors like Iran and Pakistan whose major concern is that of migrants, which presently accommodate over 2.5 million evacuated Afghans are now facing crises due to overload of refugees trying to seek refuge in Pakistan. Their registration accommodation will be a matter of grave concerns (Hussain, 2021).

Similarly, Iran has long demanded that United States soldiers withdraw from its eastern neighbor, with whom it has a 572-mile border. Major General Hossein Salami, the head of the Revolutionary Corps, announced that Iranian soldiers had controlled the eastern frontier and were closely watching the scenario (Kamel, 2015). Iran has used diplomacy to try to normalize relationships with Afghanistan. Following President Biden's announcement of the United States departure in April, Iran improved relationships with both the Taliban as well as the Afghan administration.

Officials from the Taliban as well as the Afghan administration gathered in Tehran in July to discuss settlement. Ebrahim Raisi, Iran's new president, lauded the United States military departure in August as "a chance to reestablish life, safety, and lasting peace." He called on all Afghan factions to "come to a national agreement." In Tehran, United Nation Secretary-Envoy General's for Afghanistan, Jean Arnault, visited the Ministry of Foreign affairs Muhammad Javaid Zarif to consider ways to cease the fighting. Later, Zarif praised previous Afghan President Hamid Karzai for forming a coordinating committee to engage with the Taliban and manage the handover.

Russia was surprised by the Taliban control, but relieved that one of its main opponent's (USA) prolonged armed campaign had collapsed. Senator Aleksey Pushkov, a harsh opponent of the United States, called the events "history's punishment" on "modernity and globalism (Mir, 2021). Many analysts and international affair experts compared the occurrences to the Soviet withdrawal from the country in 1988-89, claiming that strong powers failed to enforce their agenda on the nation in both cases. Others questioned if the incidents served as a warning to Russia as it prepares to exit Syria (Motafaker, 2018). The experts differed on the impact of the incident on United States foreign affairs. As per expert 
Konstantin Remchukov, the pullout might signify a major shift, with the America continuing to conduct anti-terrorist activities but no more engaging in nation-building or government transition in the name of advancing political principles. He suggested that Afghanistan will tend to be important in United States considerations, but mainly as a counter-China base. Fedor Lukyanov, a well-recognized expert, believes the United States withdrawal signals a move towards more isolationism and "bare pragmatism." The Kremlin has long been concerned about the safety danger presented by Islamic extremism. Russian diplomats who just talked with Taliban commanders indicated an interest in working with them in the coming years if the new government limit their terrorist activities. Nonetheless, Russian Foreign Affairs minister Sergey Lavrov emphasized that the Kremlin isn't in a rush to recognize the organization. Taliban soldiers, as per Russian Ambassador Zhirov, created an excellent first impact and assured the Russian Embassy's safety.

Beijing's communist overlords are pragmatist, and they've traditionally been uninterested with who governs Afghanistan as long as China's vital concerns are safeguarded. In August 2021, these vital interests will converge on a seamless transition to a new national administration capable of maintaining peace and internal order (Lubna Sunawar, 2021). Throughout the years, Beijing has retained a political engagement with the Taliban, most notably hosting a high-level group to China in July. Beijing is aggressively seeking an arrangement with the incoming Kabul government, demanding guarantees that a Taliban government will not stir unrest in Xinjiang or jeopardize China $\mathrm{s}$ financial objectives in Afghanistan.

\section{Re-emergence of Taliban: Implications for Central Asia}

Central Asian republics lived side by side with the Taliban in the 1990s, and they'll do it in the present world as well. Central Asian elites had no motive to support Kabul's weak, fractured, and corrupt administration, and had no incentive in maintaining the status order in Afghanistan. If Afghanistan becomes embroiled in civil war, it will have huge safety and financial implications for Central Asia (Scherer, 2013). A return to disorder might turn Afghanistan into a safe haven for Islamic and criminal groups, further destabilizing the region and hampering progress on economic connections, trade, and transportation among South and Central Asia. The Taliban, on the contrary, has endeavored to construct a powerful and well-organized administration in Afghanistan, a process that Central Asian leaders are all too familiar with. Asian Nations are likely to return to operating with the Taliban if they are prepared and ready to battle the Islamic State, as well as remove or encompass other multinational aggressive extremist organizations like al-Qaida and the remnants of the Islamic Movement of Uzbekistan, safeguard their boundaries, and ensure the safe pathway of products and trade among Central and South Asia. The Taliban has even declared that the drug business will be stopped. Turkmenistan, Uzbekistan, \& Tajikistan have bolstered border protection as a show of military force (Krambs, 2012).

Security forces and people from Afghanistan have fled to Tajikistan and Uzbekistan. They have also requested help from the Russia-led Cooperative Defense Treaty Group in the event of an upsurge in refugee movement over their borders. On the other side, Uzbekistan and Turkmenistan have been hesitant to admit immigrants, with Uzbek officials even sending back Afghan military personnel who escaped to Uzbekistan when their facilities were captured by Taliban troops.

\section{Future prospects for Pakistan}

Afghanistan political landscape has and continues to effect political landscape of Pakistan. One of the key reasons for Pakistan to be in the spotlight is that the current leadership of Taliban has had direct and indirect links with Pakistan. While some growing up in Pakistan, others attaining their education, to Mullah Baradar who faced jail in Pakistan; the current leadership of Taliban is related to Pakistan. It is important to keep in mind the Tehreek e Taliban factor (Mir,2021). Now with one being able to achieve power across the border, it has opened new avenues for the Taliban on this side of the border. Although, the Afghan Taliban has cleared the narrative that they have no links with TTP but the real question is the sustainability of the narrative. 
On 16 of August, Pakistan's National Security Council, directed by PM Imran Khan, and reaffirmed Pakistan's dedication to a comprehensive peaceful resolution involving all Afghan ethnicities as the path forward. The Taliban was also applauded in the formal Pakistani declaration for averting major violence in Afghanistan, and it encouraged all forces in the country to follow the rule of law, protect basic human rights, and guarantee that no terrorist organization utilizes Afghan soil against any country (Junaid, 2021). Despite the cautious government declarations, there is a sense of elation in Pakistan that its approach of balancing and assisting the Taliban has worked off. When regarded under the prism of its struggle with India, the Taliban's victory is viewed as the downfall of an Afghan administration that is pro-India. Furthermore, several right-wing leaders in Pakistan are presenting the Taliban triumph as a pan-Islamist triumph over the powerful US, an idea that attracts to right-wing internal economics. Khan previously remarked that Afghans are "shackles of slavery," referencing to Western culture's influence on Afghanistan (Lubna Sunawar, 2021). Though Pakistan says that his statements were put out of order, they have been largely understood as tacit encouragement of the Taliban's rise. Among Pakistan's elite, there are practical viewpoints concerned regarding the country's future safety implications. There is widespread fear regarding militant overflow into Pakistan, especially in view of the introduction of the Tehreek-e-Taliban Pakistan as well as the legitimizing of other insurgent and sectarian groups. As Pakistan's clout over the Taliban grows, it tries to press for a diplomatic resolution that accepts Taliban authority while also embracing other Afghan organizations (Mir, 2021).

Similarly, aside the security threats, a major concern are the economic issues. While the refugee influx has created accommodation issues on one side, economic dependency is a severe threat to Pakistani economy. Pakistan being a third world state has poverty within its own population and a state where unemployment and inflation are at rise, refugee settlement is a severe threat to economic conditions of the state (Lubna Sanawar,2021). Proper parameters need to set in order to first attain the exact amount of influx refugees. Their registrations accommodation and economic activities are the activities in which Pakistan shall have to take steps beyond its means. Anticipating a breakout from the battle, Pakistan blocked its section of the boundary before to the Taliban's conquest. After a temporary hiatus, it was restored for business with limited pedestrian access (Luke Harding, 2021). Foreign states especially Pakistan and China are expected to seek assurance from the Taliban that they will not host terrorists and that their financial concerns will take precedence. As a result, they may be in a position to lead the way to peace in Afghanistan. President Joe Biden has stated that we will remain to cooperate with Afghanistan on areas of stability and prosperity, and also through politics (Mir, 2021). The details of those projects, though, are mostly unclear, and America's eagerness to left Afghanistan's 20-year history past indicates that there will be minimal, if any, incentive to play anything more than an arms-length position there.

\section{RECOMMENDATIONS}

Since, Taliban are in power now there are a lot of implications that pose threat to the international community. Since the takeover is new and consequences are posed, and with every day changing situation, dynamics of World order are changing as well. In such circumstances faced with issues like that of Afghan Refugee, Afghanistan Governance structure, cross border terrorism and extremism, and Afghanistan making its mark in the international arena are few challenges faced. A way out can be;

- United Nations intervention on tackling the Afghan refugee crises by enabling safe houses for Afghanis seeking refuge.

- International organizations like World Bank, IMF and Asian Bank trying to negotiate the safety of people with Taliban in order to minimize migration.

- International community to offer training to the newly formed government of Taliban through capacity building.

- Neighboring states like Pakistan, Iran, Russia and China to make cooperation through the forum of SCO with Afghanistan on military training and combat warfare. 
Analyzing the Historical Perspective of Taliban in Order to Understand the Re-Emergence of Taliban and Future Prospects for Neighboring Countries

\section{CONCLUSION}

To conclude, Afghanistan has always been a focal point and as Late General Hameed Gul calls it, "the roundabout of history" central Asia politics cannot be addressed without discussing Afghanistan (Schirch, Rafiee, Sakhi \& Vardak, 2011). Post 9/11 Afghanistan was the region that shaped the new world order dynamic and now with the withdrawal of United States and newly formed government of Taliban, Afghanistan has become more significant than past. The world inspires stability in Afghanistan but what will shape the dynamics are the aspirations of Taliban. With Mullah Baradar and company Taliban looks a softer ally, but had this softness and groomed selves been decentralized to its core or not is a pivotal question. The region specifically faces challenges of security and instable Afghanistan lead to instability and turmoil in the region. Therefore, the operates morandi of Taliban can be analyzed more accurately by studying their historical dynamics in order to predict their actions.

\section{REFERENCES}

Anker, E. (2011). Terror Firma: Political Topographies of the War on Terror. Theory \& Event, 14(1), 6671.

Dr. Riaz AHMAD, H. (2020). Afghanistan: Us-Taliban peace talk: CPEC perspective. Conflict Studies Quarterly, (32), 53-73.

Ehlke, D. (2010). The Taliban and the Crisis of Afghanistan - Edited by Robert D. Crews and Amin Tarzi. Digest Of Middle East Studies, 19(2), 356-358.

Gagnon, J. (2012). The Taliban Did Not Create the Taliban, Imperialism Did. Journal of South Asian Development, 7(1), 23-42.

Hussain, F. (2021). Implications of the Enigmatic Rise of Taliban: A Historical Perspective. Global Regional Review, VI(I), 230-236.

Junaid, A. (2021). Afghan Peace Process: Prospects and Challenges. Pakistan Social Sciences

Review, 5(I), 505-515.

Kamel, K. (2015). Understanding Taliban Resurgence: Ethno-Symbolism and Revolutionary Mobilization. Studies In Ethnicity And Nationalism, 15(1), 66-82.

Krambs, T. (2012). Central Asia and the Afghanistan Security Dilemma: Amelioration, Retrograde, or Status Quo? Central Asia's Role in Regional Security Regarding Afghanistan after 2014. Connections: The Quarterly Journal, 12(2), 1-26.

Lubna Sunawar, L. (2021). Securitization of the Troubled Afghan Peace Process and the Role of Pakistan. Journal of International Peace \& Stability, 4(II), 85-97.

Luke Harding, E. (2021). The fall of Kabul: a 20-year mission collapses in a single day. Retrieved From: https://www.theguardian.com/world/2021/aug/15/the-fall-of-kabul-a-20-year-missioncollapses-in-a-single-day

Marks, T. (2012). Taliban and Anti-Taliban. Small Wars \& Insurgencies, 23(3), 569-570.

Mir, A. (2021). Pakistan in Afghan Peace Process. Daily Times. Retrieved from: https://dailytimes.com.pk/787645/pakistan-in-afghan-peace-process/

Motafaker, M. (2018). Post-taliban dönemi afganistan daki terör gruplarinin sosyal boşluk ve ayrişmalar bağlaminda incelenmesi: taliban örneği. Journal Of International Social Research, 11(61), 583-595.

Scherer, L. (2013). The Taliban (2nd ed). Greenhaven Press.

Schirch, L., Rafiee, A., Sakhi, N., \& Vardak, M. (2011). Designing a comprehensive peace process for Afghanistan. Washington, DC: U.S. Institute of Peace. 